\title{
A META-ANALYSIS OF THE INFLUENCE OF INSTRUCTIONAL MEDIA ON SPEAKING LEARNING
}

\author{
Lispridona Diner $^{1 *}$; Zukhaira²; Sherly F. Lensun ${ }^{3}$ \\ ${ }^{1}$ Japanese Language Education Study Program, Faculty Language and Art, Semarang State University \\ ${ }^{2}$ Arabic Language Education Study Program, Faculty Language and Art, Semarang State University \\ Jl. Sekaran, Gunungpati, Kota Semarang, Jawa Tengah 50229, Indonesia \\ ${ }^{3}$ Japanese Language Education Study Program, Faculty Language and Art, Manado State University \\ Jl. Raya Tondano, Koya, Tondano Sel., Kabupaten Minahasa, Sulawesi Utara 95618, Indonesia \\ 11isjoost@yahoo.com; '2zukhaira@gmail.com; 33herly_lensun@gmail.com
}

Received: $20^{\text {th }}$ April 2021/Revised: $11^{\text {th }}$ June 2021/Accepted: $14^{\text {th }}$ June 2021

\begin{abstract}
How to Cite: Diner, L., Zukhaira., \& Lensun, S. F. (2021). A meta-analysis of the influence of instructional media on speaking learning. Lingua Cultura, 15(1), 93-99. https://doi.org/10.21512/lc.v15i1.7298
\end{abstract}

\begin{abstract}
The research analyzed several related studies focusing on instructional media or learning materials and speaking learning that emphasized the development of media for learning activity. Employing a meta-analysis method, the research explored several national journal articles. Meta-analysis was a quantitative study, given its characteristics utilize statistical calculation for a practical purpose, i.e., arranging and extracting information from many data where the process could not be performed using other methods. This meta-analysis research was aimed at identifying the validity level of each data collection. Based on the results, the research concludes that instructional media development for learning speaking activities will be effective if the media are applied in universities. From the perspective of learning materials, the media will be helpful if all of the contents are applied in a book used for the learning process. This is because the teacher's book summarized everything that a teacher needed for the class, thus allowing successful and directed learning stages and more accurate accomplishment of learning objectives. From the aspect of learning, the speaking skills should focus on the types of conversation, concerning the basic level of speaking proficiency in a foreign language learning is more efficacious than the skills needed in a conversation.
\end{abstract}

Keywords: meta-analysis, instructional media, speaking learning

\section{INTRODUCTION}

Education is central to many aspects of the life of people and nations. Education refers to conscious efforts to aim for better development. In learning, education is a term describing an attempt to actualize an active learning atmosphere and develop students' self-potential in order to broaden the students' insight. According to Law of the Republic of Indonesia number 20 of 2003, education intends to enhance the intellectual life of the whole nation, thus strengthening the people's faith and piety to God the Almighty and their moral character and producing competent, healthy, and independent individuals with a high sense of responsibility for others and the nation. The government has continuously endeavored to improve the quality of the education system by providing textbooks or developing curriculum (Asrizal et al., 2018). One example of the conceptualization of the
Law is the 2013 Curriculum. This curriculum follows a tenet stating that knowledge is not something an educator can transfer to his/her students. The objective of the 2013 Curriculum is to produce active, creative, and independent students. Students have the ability to actively discover, process, construct and utilize their knowledge. A learning system based on the 2013 Curriculum refers to one that can promote students' knowledge, skills, and attitude (Siregar, Mawardi \& Elfrida, 2019).

Language skills are a universal science that underlies the development of modern communication and has an essential role in various disciplines and in advancing human thinking. Therefore, language learning should focus not only on the attainment of knowledge but also on increasing language skills achievement. One of the factors that can improve language skills, then in learning, the teacher's role in using learning media is needed. Giving students an 
opportunity to construct knowledge in their cognitive process is a must in education. This enables them to grasp and apply their knowledge. By that, it is necessary to encourage the students to be able to solve a problem, discover something for their personal needs, and work thoroughly to actualize their ideas (Regulation of the Ministry of Education No. 81A, 2013).

Over the years, the world is shocked by the emergence of the Industrial Revolution 4.0, an era when substantial changes occur in the industrial sector. This era marks a situation in which technology and information are used in every aspect of life. The revolution considerably impacts education since the condition urges many in the educational sector to equip the students with skills that meet the demand of the Industrial Revolution 4.0. Among the approaches to cope with the situation is by designing appropriate instructional media. Instructional media or learning materials are designed to help educators and learners result in more effective learning (Fitriani \& Azis, 2019). One aspect that can be used in improving speaking skills is learning (instructional) media (Fitri, 2016). Learning practices with media change the direction of teacher-centered learning interactions to learning that allows students to be actively involved in learning activities in class (Syuja'ie, Hartini, \& Agustini, 2020). Using instructional media can make time, space, and messages more efficient so that students can be invited to communicate the learning material that is delivered quickly (Khairani, Sutisna, \& Suyanto, 2019). In addition, learning media has a role in the learning process, namely as a learning aid, communication tool, and a tool for creating new things (Emda, 2011).

Given the importance of instructional media in teaching and learning activities, choosing the suitable instructional media will be the first choice for researchers before conducting research and also for teachers before delivering material, so that literacy about these aspects will be needed (Hastings \& Tracey, 2005). The use of media in learning can also affect learning speaking skills. One media, namely the animation media in learning Japanese vocabulary, can help teachers improve the Japanese speaking skills of class XI bilingual students, especially beginner Japanese learners (Lapasau, Hardi, \& Amiruddin, 2015). According to Parmawati and Inayah (2019), speaking skills are the ability to express soundarticulations or words to express thoughts in the form of ideas, opinions, desires, or feelings to speaker partners. Speaking can be interpreted as conveying one's intentions (ideas, thoughts, heart's contents) to another by using spoken language so that the meaning can be understood by others. The purpose of speaking, in general, is the urge to convey thoughts or ideas to others (who are spoken to). Meanwhile, the specific goal is to encourage people to be more enthusiastic, influence others to follow or accept opinions (ideas), convey information to the interlocutor, please others, allow the interlocutor to think and assess their ideas. Therefore, oral language skills are the main basis of language teaching because oral language skills are (1) a mode of expression that is often used, (2) it is the first form of ability that is usually learned by children, (3) it is the type of language ability most commonly used.

Several factors can be used to measure a person's speaking ability which consists of linguistic and nonlinguistic aspects. The linguistic aspects include (1) accuracy of speech; (2) appropriate placement of pressure, tone, joint, and duration; (3) choice of words;

Table 1 List of Journal and Article Titles

\begin{tabular}{|c|c|c|c|}
\hline No & Article's Title & Author(s) & Journal \\
\hline 1 & $\begin{array}{l}\text { Students' Attributions on Their English Speaking } \\
\text { Enhancement (Mali, 2015) }\end{array}$ & Yustinus Mali & $\begin{array}{l}\text { International Journal of Applied } \\
\text { Language Vol 4, No } 2 \text { (2015) }\end{array}$ \\
\hline 2 & $\begin{array}{l}\text { Peningkatan Kemampuan Bahasa Inggris } \\
\text { Mahasiswa Melalui Pengembangan Bahan Ajar } \\
\text { Berbasis TOEFL ITP Pada Mata Kuliah Bahasa } \\
\text { Inggris Geografi [Improving English Skills of } \\
\text { University Students through Developing a TOEFL } \\
\text { ITP-Based Instructional Media in English for } \\
\text { Geography] (Sugiharto et al., 2018) }\end{array}$ & $\begin{array}{l}\text { Sugiharto, Fitra Delita, } \\
\text { Muhammad Arif, Rohani }\end{array}$ & $\begin{array}{l}\text { Jurnal Geografi Vol 10, No } 1 \\
(2018)\end{array}$ \\
\hline 3 & $\begin{array}{l}\text { Development of Web-Based Learning Application } \\
\text { for Generation Z (Hariadi et al., 2016). }\end{array}$ & $\begin{array}{l}\text { Bambang Hariadi, M.J. } \\
\text { Dewiyani Sunarto, } \\
\text { Pantjawati Sudarmaningtyas }\end{array}$ & $\begin{array}{l}\text { International Journal of } \\
\text { Education Research Review } \\
\text { Vol.5 No.1 (2016) }\end{array}$ \\
\hline 4 & $\begin{array}{l}\text { Developing Speaking Materials Based on the } \\
\text { Common European Framework of Reference } \\
\text { (CEFR) for Increasing the Students' Speaking Skill } \\
\text { (Yuniarti, 2019) }\end{array}$ & Yuniarti & $\begin{array}{l}\text { Journal Pedagogy Vol } 7 \text { No } 2 \\
\text { (2019) }\end{array}$ \\
\hline 5 & $\begin{array}{l}\text { Development a Constructivist Module and Web } \\
\text { on Circle and Sphere Material with Wingeom } \\
\text { Software (Hamdunah et al., 2016) }\end{array}$ & $\begin{array}{l}\text { Hamdunah, Alfi Yunita, } \\
\text { Zulkardi, and Muhafzan }\end{array}$ & $\begin{array}{l}\text { Journal on Mathematics } \\
\text { Education } \\
\text { Vol.7 No.2 (2016) }\end{array}$ \\
\hline
\end{tabular}


Table 1 List of Journal and Article Titles (Continued)

\begin{tabular}{|c|c|c|c|}
\hline No & Article's Title & Author(s) & Journal \\
\hline 6 & $\begin{array}{l}\text { Development of Teaching Materials Based } \\
\text { Interactive Scientific Approach towards the } \\
\text { Concept of Social Arithmetic for Junior High } \\
\text { School Student (Abadi, Pujiastuti, \& Assaat, 2016) }\end{array}$ & $\begin{array}{l}\text { M K Abadi, H Pujiastuti and } \\
\text { L D Assaat }\end{array}$ & $\begin{array}{l}\text { Journal of Physics } \\
\text { Conference series } \\
\text { Vol.812 No. } 2(2016)\end{array}$ \\
\hline 7 & $\begin{array}{l}\text { Pengembangan Bahan Ajar Keterampilan } \\
\text { BerbicaraInteraktifBagiMahasiswa [Development } \\
\text { of Interactive Speaking Instructional Media for } \\
\text { University Students] (Eriyanti, 2017) }\end{array}$ & Ribut Wahyu Eriyanti & $\begin{array}{l}\text { Jurnal Keilmuan Bahasa, } \\
\text { Sastra, dan Pengajarannya } \\
\text { Vol 3, No } 1 \text { (2017) }\end{array}$ \\
\hline 8 & $\begin{array}{l}\text { Pengembangan Bahan Ajar Mata Kuliah Berbicara } \\
\text { Dengan Metode Student Facilitator and Explaining } \\
\text { di Universitas Peradaban [Development of } \\
\text { Instructional Media for Speaking Course using } \\
\text { Student Facilitator and Explaining Model in } \\
\text { Universitas Peradaban] (Irma \& Setyorini, 2018) }\end{array}$ & $\begin{array}{l}\text { Cintya Nurika Irma, Ririn } \\
\text { Setyorini }\end{array}$ & $\begin{array}{l}\text { Jurnal Kredo } \\
\text { Vol. } 2 \text { No. } 1 \text { (2018) }\end{array}$ \\
\hline 9 & $\begin{array}{l}\text { Developing EFL Learner's Speaking Ability, } \\
\text { Accuracy and Fluency(Derakhshan, Khalili, \& } \\
\text { Beheshti, 2016) }\end{array}$ & $\begin{array}{l}\text { Ali Derakhsan, Atefeh } \\
\text { Khalili, and Fatima Behesti }\end{array}$ & $\begin{array}{l}\text { EduHumaniora Jurnal } \\
\text { Pendidikan Dasar } \\
\text { Vol 5, No. } 1 \text { (2016) }\end{array}$ \\
\hline 10 & $\begin{array}{l}\text { 若手教員における「教材研究」のあり方一「 } \\
\text { 教材との対話」から深い学びへ—Wakate kyōin } \\
\text { ni okeru kyozzai kenkyü' no arikata—kyōzai to no } \\
\text { taiwa' kara fukai manabi e —" [Study of teaching } \\
\text { materials" for young teachers-from "dialogue with } \\
\text { teaching materials" to deep learning](Okazaki \& } \\
\text { Fukazawa, 2019) }\end{array}$ & $\begin{array}{l}\text { Okazaki Yutaka, } \\
\text { Fukazawa Hideo }\end{array}$ & $\begin{array}{l}\text { Graduate School of Teacher } \\
\text { Education Wakayama } \\
\text { University bulletin of Course } \\
\text { Specializing in Professional } \\
\text { Development in Education } \\
\text { Vol. } 3 \text { No. } 2 \text { (2019) }\end{array}$ \\
\hline
\end{tabular}

(4) accuracy of target conversation. Non-linguistic aspects include (1) proper posture, outlook, body language, and expression; (2) willingness to respect the conversations and ideas of others; (3) loudness of voice and fluency in speaking; (4) relevance, reasoning, and mastery of certain topics.

Meta-analysis itself is research that uses existing research results to conduct quantitative and systematic research to obtain accurate conclusions (Retnawati et al., 2018). Meta-analysis is a statistical technique that combines two or more similar studies to obtain a quantitative combination of data. Judging from the process, meta-analysis is a retrospective observational study in the sense that the researcher recapitulates the data without doing experimental manipulation. This is the same as stated by Lee (2019) that meta-analysis is a statistical method that combines and synthesizes multiple studies and integrates their results. Research that has been done on meta-analysis with the following research results. The results of the meta-analysis that have been carried out from 31 theses show ES $=0,95$, so it is concluded that the effect of using learning media affects learning outcomes with a contribution of 32,89\% and shows a moderate effect (Tumangkeng, Yusmin, \& Hartoyo, 2018).

The research is intended to explore several related studies on instructional media and speaking learning. It focuses on the development of the instructional media for learning speaking. The subject of the study (i.e., several research articles) is examined based on the content in general. Provided in Table 1 is the list of the articles.
Based on some of these research results in Table 1, the author's goal of conducting the meta-analysis is the inconsistent findings in research on the influence of instructional media on speaking learning to improve speaking skills.

\section{METHODS}

Relying on a meta-analysis method, the research explores several national journal articles. Meta-analysis is a quantitative study, given its characteristics, utilize statistical calculation for a practical purpose, i.e., arranging and extracting information from many data where the process cannot be performed using other methods. This meta-analysis research aims to identify the validity level of each collected data (Dhamayanti $\&$ Yudiarso, 2020). Meta-analysis does not focus on the conclusions obtained in various studies but rather on data, such as performing operations on variables, size of effect sizes, and sample sizes (Forero et al., 2019). The meta-analysis states the results of the study findings with the effect size (Shin, 2017). The variables of the research are instructional media and speaking skills. The reasons for choosing these ten articles are because they have indicators of variable similarity, similarity in data collection techniques, and have similar data analysis.

The aims of the meta-analysis are generally no different from other types of clinical research, they are (1) to obtain an estimate of the effect size, namely the strength of the relationship or the magnitude of the 
difference between variables, (2) inference from the data in the sample to the population, either by testing the hypothesis (p-value) or estimating (confidence interval), (3) control potential variables as confounding so as not to interfere with the statistical significance of the relationship or difference.

The present research employs a descriptive survey method that examines several articles published in both national and international journals. The survey is descriptive in nature. Research-based journals focusing on instructional media development are the population of the present research. Among the population, eight journals are selected as the sample using purposive sampling. The criteria of sampling are provided (Pigott \& Polanin, 2019); (1) the selected topic is instructional media or learning materials for enhancing speaking skills; (2) the articles are published in national and international journals; (3) calculating the effect size of each research article, including the combined effect size; (4) examining the extent to which the moderator variable contributes to the effect size; and (5) summarizing.

The observation method (using data collection tools) is used to collect the data. The results of the research are further analyzed using the effect size equation. This process is carried out by retrieving the effect size data of each article and then measuring the average to identify the categorization of each article (i.e., low, moderate, and high). This is the Cohen's effect size equation adopted by Glass (Leo, Hery, \& Kartono, 2007).

$$
\bar{\delta}=\frac{\overline{\mathbf{Y}}_{\mathrm{e}}-\overline{\mathbf{Y}}_{\mathrm{c}}}{\mathbf{S}_{\mathrm{c}}}
$$

Where:

$$
\begin{array}{cl}
\overline{\boldsymbol{\delta}} & : \text { Effect size } \\
\mathrm{Y}_{\mathrm{e}} & \text { : Average score of the treatment group } \\
\mathrm{Y}^{\mathrm{c}} & \text { : Average score of the control group } \\
\mathrm{S}_{\mathrm{c}} & \text { : Standard deviation of the control group }
\end{array}
$$

The criteria of the effect size are effect size $\leq$ 0,15 , the effect can be ignored, $0,15<$ effect size $\leq 0,40$, low category effect, $0,40<$ effect size $\leq 0,75$, moderate category effect, $0,75<$ size $\leq 1,10$ high category effect, $1,10<$ effect size $\leq 1,45$, very high category effect, and $1,45<$ effect size with significant contribution.

\section{RESULTS AND DISCUSSIONS}

The significance of speaking activities in language learning is based on the article. From the research, the total number of articles for learning media in accordance with the research objectives is ten articles. The details are as in Table 2 .

Based on Table 2, it is known that there are five studies with high effect size prices, three studies with medium effect size prices, and one study with low effect size prices. From the calculation, the total value is $0,97(\mathrm{SD}=0,69)$.

Table 2 The Significance of Speaking Activities in a Language Learning Based on the Articles

\begin{tabular}{cccc}
\hline No & Article Code & ES & Category \\
\hline 1 & OY & 0,94 & High \\
2 & ES & 0,92 & High \\
3 & YI & 0,83 & High \\
4 & HA & 0,80 & High \\
6 & AP & 0,71 & High \\
7 & YN & 0,62 & Medium \\
8 & BD & 0,54 & Medium \\
9 & RW & 0,50 & Medium \\
10 & CN & 0,49 & Low \\
\hline
\end{tabular}

Table 3 presents information regarding the significance of speaking activities in language learning based on the education level.

Table 3 The Significance of Speaking Activities in a Language Learning Based on the Education Level

\begin{tabular}{clc}
\hline No & \multicolumn{1}{c}{ Education Level } & ES \\
\hline 1 & Junior high & 0,41 \\
2 & Senior high & 0,93 \\
3 & University & 1,12 \\
\hline
\end{tabular}

According to the analysis results, the speaking activities in junior high schools have a moderate significance on language learning. This differs from the one at the senior high level as the activities have a higher contribution to the language class. The speaking activities at the university level are significantly impactful on the language class. This means that the use of learning media that has the greatest influence on students' speaking skills is applied in university.

Table 4 The Significance of a Language Learning Based on the Instructional Media

\begin{tabular}{clc}
\hline No & Instructional Media/Materials & ES \\
\hline 1 & Web & 0,61 \\
2 & Module & 0,98 \\
3 & Student Worksheet & 1,09 \\
4 & Books & 1,20 \\
5 & Visual Media & 1,25 \\
\hline
\end{tabular}

Table 4 displays information regarding the significance of language learning based on the 
instructional media or learning materials. Based on Table 4, visual media are the learning materials with the highest significance to language learning. The second highest significance is student books, and it is followed by modules and web.

The effect size is comparable to one another because it is applied the same as the z-value (Patel et al., 2021). Several things can be the reasons why visual media is able to make a significant contribution to improving student learning speaking activities among them. It can improve vocabulary mastery, and understanding the context of speaking (pragmatics) increases interaction between student and teacher or student and student in the class. The calculation of the effect size price in each learning media varies; some have a negligible effect, such as web-based media $\mathrm{ES}=0,61$, and learning media with a high influence, namely visual media with $\mathrm{ES}=1,25$. From these results, it can be taken an average of $\mathrm{ES}=1,04$ so that the ten articles have a high effect on speaking skills activities. Based on Table 4, it can be seen that visual media has a high ES value. This is relevant to Eriyanti's (2017) explanation that visual media relies on vision because it is in accordance with language learning activities that often carry out speaking practice activities (Oradee, 2012). The function of visual media attention is the core, which directs and brings students' attention to concentrate on lessons related to the visual meaning that accompanies or displays the text of the subject matter. Appropriate learning media is also a teacher's strategy in giving learning to students; media is related to learning resources in a broad sense. Learning resources can be in the form of messages, tools (media), techniques, and the environment. It can be interpreted that instructional media can make it easier as a tool used by teachers in the learning process, media in doing something such as providing learning to students.

Instructional media will help the student learning process in teaching, which can be considered to be helpful for student motivation and improve learning outcomes to be achieved. The benefits of using visual learning media in the teaching and learning process include teaching methods will be more varied, not only using lecture methods which can make students bored. In the teaching and learning process, the presence of the media has significant meaning because it can represent what the teacher is unable to say through certain words or sentences. Even the abstractness of the material can be concrete with the presence of the media.

Table 5 shows the information regarding the significance of learning speaking according to the types of speaking activities.

Based on Table 5, lecturing is the type of speaking activity with the highest significance to language learning. The second highest significance is a conversation and followed by speech and discussion. The reason is because a conversation is a dialogue between two or more people. An example of establishing communication through spoken language is by telephone and in writing (in chat rooms). This conversation is interactive in nature, namely communication spontaneously between two or more people. The conversation is a natural and informal form of verbal expression. Students are given the opportunity to chat in small groups. They learn about the role of speaking in developing knowledge.

Table 5 The Results of the Types of Speaking Activities

\begin{tabular}{clc}
\hline No & Type of Speaking Activities & ES \\
\hline 1 & Discussion & 0,31 \\
2 & Speech & 0,39 \\
3 & Conservation & 1,60 \\
4 & Lecturing & 0,71 \\
\hline
\end{tabular}

The effect size, which shows the magnitude of the effect of a treatment or the strength of the relationship between two variables, is an essential component in the meta-analysis because it provides information from the summary results (Denson \& Seltzer, 2011). By determining the effect sizes of each research, the average overall effect sizes can be determined (Oktradiksa \& Fitriansyah, 2017). The research indicates that the effect size of the two variables is high, namely instructional media dan speaking activities. The effect size of instructional media of student visual media is 0,98 , and the effect size of learning speaking based on the types of speaking activities is 1,60 .

\section{CONCLUSIONS}

The research summarizes that instructional media development for learning speaking will be effective if the media are implemented in universities. With the existence of learning media, oral and written traditions in the learning process, it can be enriched with various learning media. With the availability of instructional media, teachers can create various classroom situations, determine various teaching methods, and create a healthy emotional climate among students. Instructional media can also build interactive and effective communication between lecturers and students. They are applied in college because the learning process leads to particular skills, such as language learning and speaking skills.

From the perspective of learning materials, the media would be helpful if all of the contents are integrated into a book. This is because the teacher's book summarizes everything a teacher needs for the class, thus allowing successful and directed learning stages and more accurate accomplishment of learning objectives. From the aspect of learning, the speaking skills should focus on the types of conversation. Concerning the basic level of speaking skills in a foreign language, learning is more efficacious 
compared to the skills needed in a conversation. From the results of the meta-analysis in the research, it is concluded that the use of instructional media is very influential in the learning process of speaking skills. Meanwhile, the use of instructional media can be carried out at the university level.

\section{ACKNOWLEDGEMENTS}

The researchers wish to express their deepest gratitude to The Semarang State University and Manado State University for allowing them to conduct the research.

\section{REFERENCES}

Abadi, M. K., Pujiastuti, H., \& Assaat, L. D. (2016). Development of teaching materials based interactive scientific approach towards the concept of social arithmetic for junior high school student. Journal of Physics: Conference Series, 812, 1-6. https://doi. org/10.1088/1742-6596/812/1/012015.

Asrizal, A., Amran, A., Ananda, A., Festiyed, F., \& Sumarmin, R. (2018). The development of integrated science instructional materials to improve students' digital literacy in scientific approach. Jurnal Pendidikan IPA Indonesia, 7(4), 442-450. https://doi. org/10.15294/jpii.v7i4.13613.

Denson, N., \& Seltzer, M. H. (2011). Meta-analysis in higher education: An illustrative example using hierarchical linear modeling. Research in Higher Education, 52, 215-244. https://doi.org/10.1007/ s11162-010-9196-X.

Derakhshan, A., Khalili, A. N., \& Beheshti, F. (2016). Developing EFL learner's speaking ability, accuracy, and fluency. Jurnal English Language and Literature Studies, 6(2), 177-186. https://doi.org/10.5539/ells. v6n2p177.

Dhamayanti, T. P., \& Yudiarso, A. (2020). The effectiveness of mindfulness therapy for anxiety: A review of meta analysis. Journal Psikodimensia, 19(2), 174-183.

Emda, A. (2011). Pemanfaatan media pembelajaran Biologi di sekolah. Jurnal Ilmiah Didaktika, 12(1), 149-162.

Eriyanti, R. W. (2017). Pengembangan bahan ajar keterampilan berbicara interaktif bagi mahasiswa. Kembara: Jurnal Keilmuan Bahasa, Sastra, dan Pengajarannya, 3(1), 98-106. https://doi. org/10.22219/kembara.v3i1.4381.

Fitri, T. T. (2016). Pengembangan bahan ajar digital menggunakan multi representasi dinamik pada materi Gerak Melingkar Beraturan (GMB) untuk meningkatkan hasil belajar pada siswa SMA kelas $X$. Bandung: Universitas Pendidikan Indonesia.

Fitriani, Y., \& Azis, I. A. (2019). Literasi era revolusi industri 4.0. Prosiding Senabasa (Seminar Nasional Bahasa dan Sastra). pp 100-104.

Forero, D. A., Lopez-Leon, S., González-Giraldo, Y., \& Bagos, P. G. (2019). Ten simple rules for carrying out and writing meta-analyses. Journal Plos Computational Biology, 15(5), e1006922. https://
dx.doi.org/10.1371\%2Fjournal.pcbi.1006922.

Hamdunah., Yunita, A., Muhafzan., \& Zulkardi. (2016). Development a constructivist module and web on circle and sphere material with wingeom software. Journal on Mathematics Education, 7(2), 109-116. http://dx.doi.org/10.22342/jme.7.2.3536.109-116.

Hariadi, B., Sunarto, M. J. D., \& Sudarmaningtyas, P. (2016). Development of web-based learning application for generation z. International Journal of Education Research Review, 5(1), 60-68. http://doi. org/10.11591/ijere.v5i1.4523.

Hastings, N. B., \& Tracey, M. W. (2005). Does media affect learning: Where are we now? TechTrends Linking Research and Practice to Improve Learning, 49(2), 28-30.

Irma, C. N., \& Setyorini, R. (2018). Pengembangan bahan ajar mata kuliah berbicara dengan metode student facilitator and explaining di Universitas Peradaban. Jurnal Kredo, 2(1), 157-169. https://doi. org/10.24176/kredo.v2i1.2573.

Khairani, M., Sutisna, S., \& Suyanto, S. (2019). Studi meta-analisis pengaruh video pembelajaran terhadap hasil belajar peserta didik. Journal of Biological Education and Research, 2(1), 158-166. https://doi. org/10.30821/biolokus.v2i1.44.

Lapasau, M., Hardi, R., \& Amiruddin, S. (2015). Metode role play dan media animasi untuk meningkatkan keterampilan berbicara bahasa Jepang di SMA. Jurnal Ilmu Kependidikan, 2(1), 22-37. http://dx.doi. org/10.30998/fjik.v2i1.372.g1269.

Lee, Y. H. (2019). Strengths and limitations of meta-analysis. The Korean Journal of Medicine, 94(5), 391-395. https://doi.org/10.3904/kjm.2019.94.5.391.

Leo, S., Hery, K., \& Kartono. (2007). Pengembangan Pembelajaran IPA SD. LPJJ PGSD.

Mali, Y. (2015). Students' attributions on their English speaking enhancement. Internasional Journal of Educational and Review, 4(2), 32-43. https://doi. org/10.17509/ijal.v4i2.681.

Okazaki, Y., \& Fukazawa, H. (2019). Wakate kyōin ni okeru 'kyōzai kenkyū' no arikata —-kyōzai to no taiwa' kara fukai manabi e - Graduate School of Teacher Education Wakayama University Bulletin of Course Specializing in Professional Development in Education, 3(2), 9-14. https://doi.org/10.19002/ AA12779311.3.9

Oktradiksa, A., \& Fitriansyah, A. (2017). Pengaruh media pembelajaran melalui keterampilan berbicara siswa mata pelajaran Bahasa Indonesia di Madrasah Ibtiaiyah An-Nur kabupaten Magelang. Jurnal Wahana Akademika, 4(2), 219-235. https://doi. org/10.21580/wa.v4i2.2077.

Oradee, T. (2012). Developing speaking skills using three communicative activities (Discussion, problemsolving, and role-play). International Journal of Social Science and Humanity, 2(6), 533-535. https:// doi.org/10.7763/IJSSH.2012.V2.164.

Parmawati, A., \& Inayah, R. (2019). Improving students' speaking skill through English movie in scope of speaking for general communication. Journal of English Language Teaching in Indonesia, 7(2), 43- 
53. https://doi.org/10.22460/eltin.v7i2.p43-53.

Patel, T. K., Patel, P. B., Barvaliya, M., Vijayalaxmi., \& Bhalla, H. L. (2021). Efficacy and safety outcomes with remdesivir in COVID-19 patients: A metaanalysis. World Journal of Meta-Analysis, 9(1), 7487. https://dx.doi.org/10.13105/wjma.v9.i1.74.

Pigott, T. D., \& Polanin, J. R. (2019). Methodoligical guidance paper: High quality meta-analysis. Review of Educational Research, 90(1), 24-46. https://doi. org/10.3102/0034654319877153.

Republic of Indonesia. (2003). Law of the Republic of Indonesia number 20, year 2003 on national education system. Jakarta: Sekretariat Negara. (Law of itu italics)

Republic of Indonesia. (2013). Education and culture minister's rules Republic of Indonesia number 81A year 2013 about the implementation of the curriculum. State news of Republic of Indonesia no. 972, 2013. Jakarta: Sekretariat Negara. (Yg di italics judulnya yg education.....)

Retnawati, H., Apino, E., Djidu, H., Kartianom, \& Anazifa, R. D. (2018). Pengantar analisis meta. Jakarta: Parama Publishing.

Shin, I. S. (2017). Recent research trends in meta-analysis. Asian Nursing Research, 11(2), 79-83. https://doi. org/10.1016/j.anr.2017.05.004.
Siregar, L. P., Mawardi, \& Elfrida. (2019). Implementasi Kurikulum 2013 terhadap karakter siswa di MAN 2 Model Padangsidimpuan Sumatera Utara. Jurnal Jeumpa, 6(1), 160-165. https://doi.org/10.33059/ jj.v6il.1410.

Sugiharto, Delita, F., Arif, M., \& Rohani. (2018). Peningkatan kemampuan bahasa Inggris mahasiswa melalui pengembangan bahan ajar berbasis TOEFL ITP pada mata kuliah Bahasa Inggris Geografi. Jurnal Geografi, 10(1), 42-50. https://doi.org/10.24114/ jg.v10i1.8617.

Syuja'ie, A. W., Hartini, S., \& Agustini, F. (2020). Animasi interktif media pembelajaran bahasa Jepang dasar untuk siswa sekolah menengah kejuruan. Journal of Students' Research in Computer Science, 1(1), 1522. https://doi.org/10.31599/jsrcs.v1i1.75.

Tumangkeng, Y. W., Yusmin, E., \& Hartoyo, A. (2018). Meta-analisis pengaruh media pembelajaran terhadap hasil belajar Matematika siswa. Jurnal Pendidikan dan Pembelajaran Khatulistiwa, 7(6), 1-11.

Yuniarti. (2019). Developing speaking materials based on the Common European Framework of Reference (CEFR) for increasing the students' speaking skill. Journal Pedagogy, 7(2), 143-156. https://doi. org/10.32332/pedagogy.v4i2.384. 